\section{俩 Heighten Science \\ P U B L I C I T I O N S Corporation \\ ISSN \\ 2576-9510}

\title{
Exploring novel medical applications for commonly used veterinary drug (tilmicosin antibiotic)
}

\author{
Fatma I Abo El-Ela ${ }^{1 *}$ and El-Banna $\mathrm{HA}^{2}$ \\ 'Lecturer of pharmacology, Department of Pharmacology, Faculty of Veterinary Medicine, Beni- \\ Suef University, Beni-Suef 62511, Egypt \\ ${ }^{2}$ Professor of pharmacology, Department of Pharmacology, Faculty of Veterinary Medicine, \\ Cairo University, PO Box 12211 Giza, Egypt
}

\begin{abstract}
*Address for Correspondence: Fatma I Abo El-Ela, Lecturer of pharmacology, Department of Pharmacology, Faculty of Veterinary Medicine, Beni-Suef University, Beni-Suef 62511, Egypt, Tel: +201152460404, Fax: +20822327982; Email: fa.pharma@yahoo.com;

fatma.aboel3la@vet.bsu.edu.eg
\end{abstract}

Submitted: 02 August 2017

Approved: 28 August 2017

Published: 31 August 2017

Copyright: @2 2017 El-Ela FIA, et al. This is an open access article distributed under the Creative Commons Attribution License, which permits unrestricted use, distribution, and reproduction in any medium, provided the original work is properly cited.

Keywords: Tilmicosin; Anti-oxidant; Wound healing; Rats

\section{Abstract}

Tilmicosin (TMC) is a semi synthetic macrolide antibiotic of tylosin derivatives commonly used by veterinaries, has been shown to reveal beneficial pharmacological activities. In the current study, the potential wound healing activity, Anti-oxidant effect (ulcer and hepatoprotective) were investigated. Anti-inflammatory, antipyretic, analgesic (central and peripheral), hypnotic and antispasmodic activity were also screened. This study included adult both sexes of rats (200-250 gm), mice (20-25 gm) and adult rabbits. Experimental wound was induced on the anterior-dorsal side of each rat whereas, ulcer induced by ethanol causing mucosal damage in rats. The oral anti-inflammatory induced through formalin producing edema, antipyretic (Brewer's yeast induced hyperthermia) and analgesic (writhing test, hot plate method, tail immersion method) while hypnotic effects induced through thiopental sodium. Anti-spasmodic effect on isolated organs (intestinal and uterine muscles) using new method of Modular Single Chamber Organ Bath were carried out on experimental animals. Tilmicosin antibiotic at different two doses of 20 and $40 \mathrm{mg} / \mathrm{kg}$ b.wt., has an important role in treatment of ulcer (cytoprotective effect) and improvement the wound healing processes besides anti-inflammatory, analgesics, and anti-pyretic effects. Tilmicosin revealed also hypnotic and intestinal anti-spasmodic effects but showed Pharmacovigilence hepatotoxic effect through the histopathological studies which revealed sever hepatic damage especially at larger dose.

\section{Introduction}

Pharmacoepidemiology is a relatively new branch of pharmacological science that explores beneficial effect or toxicity of drugs [1] while Pharmacovigilence any activities belong to determination, detection, understanding and prevention of drugs adverse effects or other related problems [2]. On the same way it's important to explore the beneficial effects of commonly used veterinary drug like tilmicosin especially in the best of our knowledge no tilmicosin resistance had been reported.

Macrolide antibiotics are structurally similar drugs with bacteriostatic effect. Large number of drugs in this class had been isolated from genus Streptomyces of the soil bacteria [3]. Tilmicosin is a 16-membered semisynthetic macrolide antibiotic acts by inhibiting the bacterial protein synthesis through binding with $50 \mathrm{~S}$ ribosomal subunit [4]. Its high dose has some adverse effects like cardio-toxic, anaphylaxis, temporary swelling at the site of injection and collapse [5,6] even though, tilmicosin has an important role in treatment of ulcer treatment and wound healing as will be investigated in this study. The macrolide antibiotic like clarithromycin drug is, till now, one of the most active antimicrobial agents against Helicobacter pylori in vitro [7]. It is relatively stable in the presence of gastric acid [8], so it's important to determine the effect of tilmicosin on induced ulcer in rats. 
standard (Ranitidine ${ }^{\circledR}, 50 \mathrm{mg} / \mathrm{kg} \mathrm{b.wt}$.) and treated groups (20 and $40 \mathrm{mg} / \mathrm{kg} \mathrm{b.wt.).} \mathrm{All}$ drugs were given orally, once daily, for 6 days. At $7^{\text {th }}$ day, animals were starved for 24 hours but allowed free access to water except for the last hour before ulcer induction. Gastric ulcer was induced by oral administration of absolute ethanol in a dose level of $5 \mathrm{ml} / \mathrm{kg}$ body weight for all groups then oral administration of Ranitidine ${ }^{\circledR}$ for the second group and tilmicosin phosphate for third and fourth groups after one hour. Oral administration of absolute ethanol induces gastric lesion in rats as recorded by [11] with slight modification and the method of its calculation according to [12]. The gastric mucosa was inspected for the occurrence of ulcers and their numbers were counted with the aid of an illuminated magnifying lens (10x) as [13]. The sum of the total length of long ulcers and hemorrhagic spots in each group of rats was divided by the number of animals to calculate the ulcer index (mm) [12]. The percentage of protection was calculated according to the method described by [14].

$$
\% \text { of protection }=\frac{(\text { ulcer index of control }- \text { ulcer index of treated })}{\text { ulcer index of control }} \mathrm{X} 100
$$

\section{Measurements of the wound healing activity}

Total of 18 rats of both sexes weighing 150-200 gm b.wt. were used. After induction of anesthesia by I/P injection of ketamine $5 \%$ (90 mg/kg b.wt.) and xylazine hydrochloride $2 \%$ ( $5 \mathrm{mg} / \mathrm{kg}$ b.wt.), the fur of each rat was aseptically removed and predetermined area marked on the back of animals. Surgical wound of $(1 \mathrm{~cm} \times 1 \mathrm{~cm})$ was made on the back of each rat after keeping them on ventral posture. The wound healing activity of the tilmicosin phosphate was determined according to the method stated by [15]. Rats divided into control, standard (Fucidine ${ }^{\circledR}$ ointment) and treated (tilmicosin ointment $10 \%$ based on Vaseline). The ointments were topically applied daily, starting $2 \mathrm{~h}$ post-operation, on the wound area until wound completely healed. All rats were monitored daily and any wound fluid or evidence of infection or other abnormalities were noted. Wound contraction percentage and wound closure time were used to assess wound-healing activity. The wound size was computed on days 4 , 8,12 and 16 day post-operation. The wound healing percentage was calculated by the Walker formula [16].

$$
\text { Percentage of wound size }=\frac{\text { Wound area on day } \mathrm{X}}{\text { Wound area on day zero }} \mathrm{X} 100
$$

\section{Assessment of the Hepatotoxicity}

Hepatotoxicity induced by paracetamol (400 mg/kg b.wt.) oral administration for seven days. Five groups divided into control negative group which received D.W, Control positive administered paracetamol, standard group received $200 \mathrm{mg} / \mathrm{kg} \mathrm{b}$. wt. of standard drug Silymarin and paracetamol, treated group administered tilmicosin phosphate and paracetamol for seven days [17].

\section{Sample collection}

Animals of all the groups were sacrificed by cervical decapitation after anesthesia with Ketamine mixed with xylazine with $(0.1 \mathrm{ml} / 100 \mathrm{gm})$ on eighth day. Blood sample of each group was collected separately into sterilized dry centrifuge tubes and allowed to coagulate for $30 \mathrm{~min}$ at $37^{0}$.

\section{Evaluation of effect on biochemical variables}

The clear serum obtained after centrifugation was used for the estimation of serum alanine amino transferase, serum aspartate amino transferase, alkaline phosphatase, gamma glutamyl transferase, serum protein, cholesterol [18]. 


\section{Histopathology study}

Liver is dissected out and the liver samples were excised from the experimental animals of each group and washed with the normal saline. Initially the materials were fixed in $10 \%$ buffered neutral formalin and then with bovine solution. They were processed for paraffin embeddingfollowing the microtome technique.

The sections were taken at $5 \mu$ thickness processed in alcoholxylene series and were stained with haematoxylin and eosin. The sections were examined microscopically for the evaluation of histopathological changes.

\section{Evaluation the Analgesic effect of tilmicosin phosphate}

Hot plate method: Twenty mice of both sexes, weighing 20-30 gm served as control, standard Paracetamol ${ }^{\circledR}(50 \mathrm{mg} / \mathrm{kg}$ b.wt.) and treated groups. The analgesic effect of tilmicosin phosphate was determined using hot plate method as described by [19]. Each mouse was placed individually in a beaker of two liters capacity set over hot plate thermostatically controlled adjusted at $\left(56 \pm 0.5^{\circ} \mathrm{C}\right)$. The time elapsed until the mouse licks its paw or jumps, was considered as reaction time for the analgesic activity. The reaction time was recorded at $0,1,2,3$ and $5 \mathrm{~h}$ after administration of tilmicosin phosphate and Paracetamol ${ }^{\circledR}$.

Writhing test: An acetic acid-induced abdominal constriction (writhing test) in mice was performed according to [20]. For this purpose twenty mice of both sexes weighing 20-30 gm were divided into four equal groups as the same previous classified groups. After 30 minutes, each mouse was injected intraperitoneally $0.7 \%$ of an aqueous solution of acetic acid $(10 \mathrm{ml} / \mathrm{kg}$ b.wt.) and the mice were then placed in transparent boxes for observation. The number of animals showing writhes in each treated group was counted every one h for four hrs. after acetic acid injection and compared to that of the control group. The number of writhes was recorded and the percentage of protection was calculated using the following equation:

$$
\text { Percentage of protection }=\frac{\text { No. of animals that didn't writhe }}{\text { Original no. of animals }} \mathrm{X} 100
$$

Tail immersion method: The animals (20 mice) were screened for sensitivity by immersing the tail of the mice gently in hot water maintained at $55-55.5^{\circ} \mathrm{C}$. For this purpose twenty mice of both sexes weighing 20-30 gm were divided into four equal groups as the same previous classified groups. Following administration of the samples, reaction time was measured at $0,15,30,45$ and $60 \mathrm{~min}$ [21].

\section{Evaluation of the Anti-pyretic effect}

Twenty fasting rats divided into four equal group's control, standard (paracetamol, $150 \mathrm{mg} / \mathrm{kg}$ b.wt.) and treated with tilmicosin (20 and $40 \mathrm{mg} / \mathrm{kg}$ b.wt.). Basal rectal temperature was recorded for each rat using digital thermometer then hyperthermia was induced by subcutaneous injection of $12.5 \%$ yeast suspension in normal saline solution at dose level of $1 \mathrm{ml} / 100 \mathrm{~g}$ body weights. After $18 \mathrm{hrs}$. the elevated body temperature of each rat was rectally measured (animals that showed elevations of $0.3-0.5^{\circ} \mathrm{C}$ in rectal temperature were selected). The antipyretic effect of the tilmicosin phosphate was determined according to [22]. Rectal temperature of each rat was then recorded for four hours at one hour interval.

\section{Evaluation of the Anti-inflammatory effect}

Equal different four groups of rats, control, standard (diclofenac sodium in a dose of (30 mg/kg body weight, orally) and tilmicosin treated groups. The thickness of the left hind paw of each rat was measured in $\mathrm{mm}$. After $30 \mathrm{~min}$ of tilmicosin phosphate administration, inflammation was induced by subcutaneous injection of $0.1 \mathrm{ml}$ of 
formalin (6\%) in normal saline into the left hind paw of all animals. The paw thickness was measured hourly for four hrs post administration of the tilmicosin phosphate [23].

\section{Evaluation the effect of Tilmicosin phosphate on sleeping time}

Fifteen mice of both sexes weighing 20-30 gm were divided into three groups (eight mice of each), control and treated ( 20 and $40 \mathrm{mg} / \mathrm{kg} \mathrm{b.wt}$.). After one hour all groups were intraperitoneally injected with thiopental sodium at dose level of $30 \mathrm{mg} / \mathrm{kg}$ body weight. The time elapsed from losing to regain of rightening reflex was determined as the sleeping time [24].

\section{Measurement of the effect on intestinal motility of rabbits}

This effect was studied using Modular Single chamber organ bath LE11100 which consists of: Modular organ bath with single chamber system LE11100 (25 ml Panlab s. l., AD Instruments Pty Ltd, Spain) was designed for an easy maintenance of isolated tissues in physiological conditions over long periods, thus making it possible to record responses produced in them by drugs. Force transducer MLT0201 (AD Instruments Pty Ltd, Spain) was responsible for transmission of the electrical signals from the tested tissue to bridge amplifier to be amplified. Bridge amplifier (FE 221) was designed for amplification of the electrical signals through connection of the power lab to most direct current (DC) bridge transducers including force transducer. Power lab ${ }^{\circledR}$ with lab chart software ${ }^{\circledR}$ : The electrical signals from the transducer was amplified by bridge amplifier which connected to the power lab that responsible for conversion the electrical signals to digital signals and recorded using Chart software (AD Instruments Pty Ltd, Australia). Termotronic (immersion thermostate 3000389) was designed for provide optimum temperature inside the organ bath.

This apparatus was prepared by adjusting the temperature in the outer bath at $37^{\circ} \mathrm{C}$, filling the tissue bath $(25 \mathrm{ml}$ capacity) with tyroide's solution and allow the oxygen to pass through it freely. The method described by [25] was used. Duodenal strip of about $3 \mathrm{~cm}$ from freshly slaughtered rabbits was suspended in the organ bath by attaching one end with a hook and the other end was tied by a thread, attached to force transducer. The tissues were allowed to equilibrate for at least 30 minutes prior to the addition of any drug. Normal rhythmic contractions were recorded and the effect of graded concentrations of tilmicosin phosphate was demonstrated.

After tracing the normal intestinal motility and the effect of graded increased doses of tilmicosin phosphate; the possibility of an atropine like activity was studied by adding acetylcholine $\left(0.25 \mathrm{ml}\right.$ of $\left.1.1 \times 10^{-7} \mathrm{mmol} / \mathrm{l}\right)$ in the presence of effective dose of the drug $(2.5 \mathrm{gm} / \mathrm{ml}$ bath). Furthermore; the probability of ganglionic blocking activity was investigated by adding small dose of nicotine $(0.125 \mathrm{ml} \mathrm{of} 10 \mu \mathrm{g} / \mathrm{ml})$ in the presence of effective dose of the drug $(2.5 \mathrm{gm} / \mathrm{ml} \mathrm{bath})$.

\section{Measurement of the effect on uterine motility in female rats}

The aim of this study is to investigate the effect of tilmicosin phosphate on isolated uteri of rats at various stages of sex cycle. In this respect, mature female rats at various stages of sex cycle (non-estrus, estrus and pregnancy) were used. Vaginal smears were performed for determining the stages of sex cycle of animals [26]. Animals after being examined were killed, their uteri were dissected out and one uterine horn was suspended in the organ bath containing warm oxygenated dale's solution at $32^{\circ} \mathrm{C}$. Uterine horn was attached from one end to a hook and the other end was tied by a thread, attached to force transducer. The normal rhythmic motility of the uteri was recorded and the effect of graded concentrations of tilmicosin phosphate was determined at different stages of sex cycle.

\section{Statistical Analysis}

The results were expressed as mean \pm standard error of mean (S.E.M.). Statistical significance was determined by one-way analysis of variance (ANOVA) according to 
[27] followed by Turkey's post-hoc test for multiple comparisons using SPSS (version 20.0) software (IBM SPSS Statistic 20.0, Armonk, NY, USA). The $P$ values less than 0.05 were considered statistically significant.

\section{Results}

\section{Anti-ulcerogenic effect of tilmicosin phosphate}

Data in Table 2 and Figure 1 presents the percentages of protection and the ulcer index in different treated groups. Pre-treatment the rats for one week with tilmicosin phosphate at dose levels of 20 and $40 \mathrm{mg} / \mathrm{kg} \mathrm{b.wt}$, respectively and the second group with Ranitidine ${ }^{\circledR}(50 \mathrm{mg} / \mathrm{kg}$ b.wt.) significantly $(P<0.05)$ decreased the ulcer index

Table 2: Anti-ulcerogenic effect of tilmicosin phosphate in rats $(n=7)$.

\begin{tabular}{|c|c|c|c|c|}
\hline \multirow{2}{*}{ Group } & \multirow{2}{*}{ Dose $\mathrm{mg} / \mathrm{kg}$. body weight } & \multicolumn{2}{|c|}{ Mean \pm Standard error } & \multirow{2}{*}{ percentage of protection } \\
\hline & & Ulcer number & Ulcer index & \\
\hline Control & - & $25.2 \pm 1.01^{c}$ & $65.7 \pm 2.3^{c}$ & 0 \\
\hline $\begin{array}{c}\text { Standard } \\
\text { (Ranitidine }^{\circledR} \text { ) }\end{array}$ & 50 & $7.6 \pm 0.9^{b}$ & $23.8 \pm 0.5^{\mathrm{ab}}$ & 63.77 \\
\hline \multirow{2}{*}{ Tilmicosin phosphate } & 20 & $15.8 \pm 1.2^{\mathrm{a}}$ & $28.2 \pm 1.06^{\mathrm{ab}}$ & 57.07 \\
\hline & 40 & $4.4 \pm 0.5^{d}$ & $11.6 \pm 1.8^{\mathrm{a}}$ & 82.34 \\
\hline
\end{tabular}

Means within the same column having the same or no superscripts denote non-significant variations $(p>0.05)$ a: represent the significant level at $(p<0.001)$; b: Represent the significant level at $(p<0.01)$; $\mathbf{c}$ and $d$ : represent the significant level at $(\mathrm{p}<0.05)$.

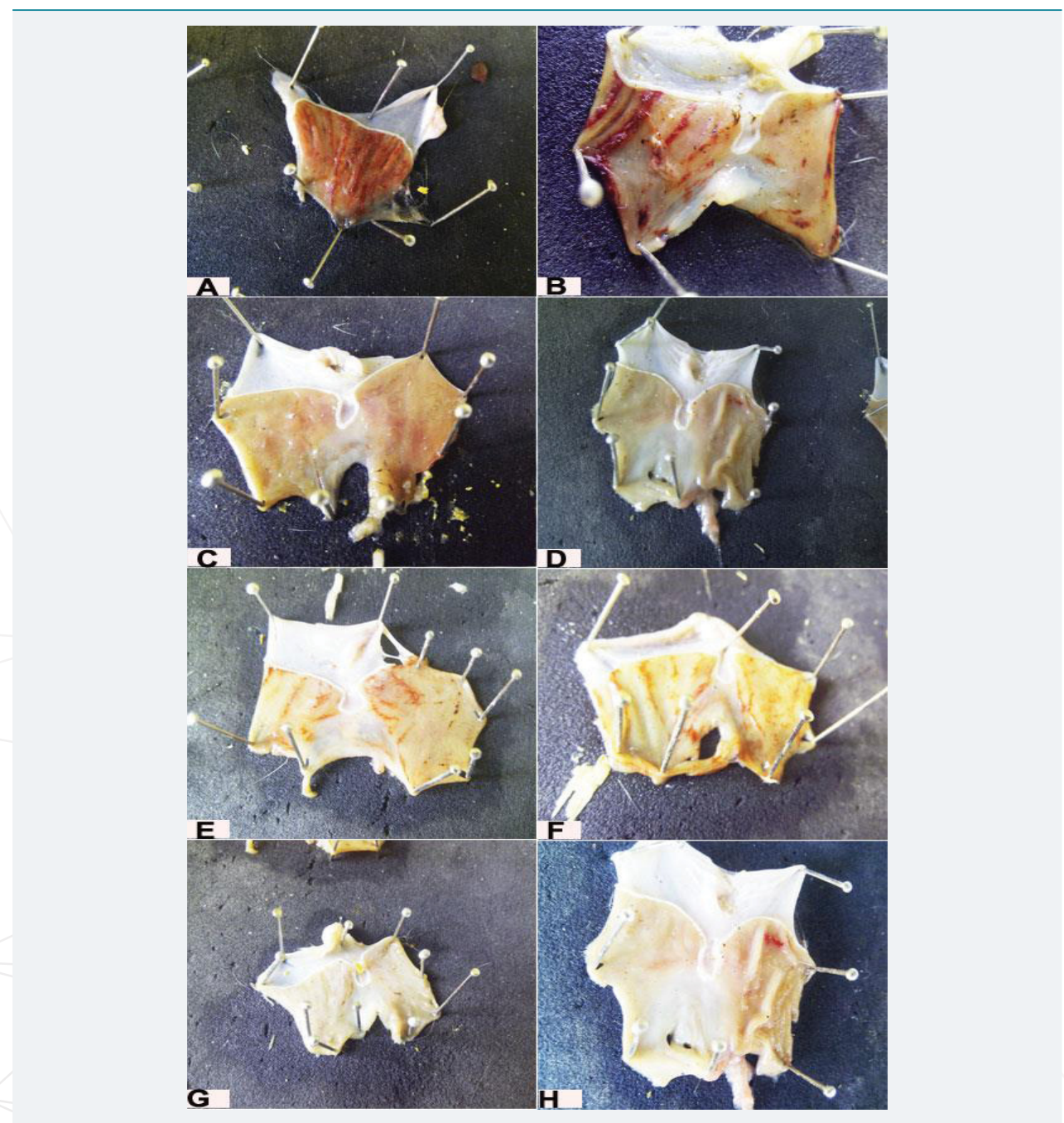

Figure 1: Anti-ulcerogenic effect of tilmicosin phosphate in rats. $(n=7)$

A,B: Control positive group (ethyl alcohol only); C,D: Standard group (Ranitidine® and ethyl alcohol).

E,F: Tilmicosin treated group $(20 \mathrm{mg} / \mathrm{kg})($ tilmicosin and ethyl alcohol); G,H: Tilmicosin treated group $(40 \mathrm{mg} / \mathrm{kg})$ (tilmicosin and ethyl alcoh 
compared with control group. The maximum percentage of gastric protection was observed at higher dose of the tilmicosin phosphate in comparison with the third and second groups that treated with the lower dose of the tilmicosin phosphate and Ranitidine ${ }^{\circledR}$.

\section{Wound healing activity of tilmicosin phosphate of Tilmicosin phosphate}

Topical application of tilmicosin phosphate in the form of ointment (10\%) daily on the wound area of treated rats, induced significant $(P<0.05)$ decrease in wound size at $4,8,12$ and 16 days of treatment respectively in comparison with the control non treated group. Similarly, the standard (Fucidine ${ }^{\circledR}$ ) ointment treated group showed significantly decrease in the wound size at 8,12 and 16 days Table 3, Figure 2. Complete wound healing was observed in the group treated with the tilmicosin phosphate ointment and standard group long the whole period of treatment in comparison to wound area of

Table 3: Wound healing activity of tilmicosin phosphate in rats. $(n=5)$.

\begin{tabular}{|c|c|c|c|c|}
\hline \multirow{2}{*}{ Group } & \multicolumn{4}{|c|}{ Wound size ( $\mathrm{mm}$ ) and Percentage of wound healing (at) } \\
\hline & $4^{\text {th }}$ day & $8^{\text {th }}$ day & $12^{\text {th }}$ day & $16^{\text {th }}$ day \\
\hline Control & $\begin{array}{c}88.00 \pm 2.00^{c} \\
(12 \%)\end{array}$ & $\begin{array}{c}62 \pm 2.1^{c} \\
(38 \%)\end{array}$ & $\begin{array}{c}43 \pm 2.1^{c} \\
(57 \%)\end{array}$ & $\begin{array}{c}30.33 \pm 0.9^{c} \\
(69.67 \%)\end{array}$ \\
\hline $\begin{array}{c}\text { Standard } \\
\text { (Fucidine }{ }^{\circledR} \text { Ointment) }\end{array}$ & $\begin{array}{c}79.3 \pm 1.2^{\mathrm{ac}} \\
(20.7 \%)\end{array}$ & $\begin{array}{l}46 \pm 2^{a} \\
(54 \%)\end{array}$ & $\begin{array}{c}18.6 \pm 1.3^{a} \\
(81.4 \%)\end{array}$ & $\begin{array}{l}7.00 \pm 1.0^{\mathrm{a}} \\
(93 \%)\end{array}$ \\
\hline Tilmicosin phosphate (Ointment) & $\begin{array}{l}71.66 \pm 4.9^{a} \\
(28.34 \%)\end{array}$ & $\begin{array}{l}40 \pm 2^{a} \\
(60 \%)\end{array}$ & $\begin{array}{c}18.6 \pm 1.3^{\mathrm{a}} \\
(81.4 \%)\end{array}$ & $\begin{array}{c}11.00 \pm 2.9^{\mathrm{a}} \\
(89 \%)\end{array}$ \\
\hline \multicolumn{5}{|c|}{$\begin{array}{l}\text { Means within the same column having the same or no superscripts denote non-significant } \\
\text { variations }(p>0.05) \text {; a: represent the significant level at }(p<0.001) \text {; b: Represent the significant level at }(p<0.01) \text {. } \\
\text { c and d: represent the significant level at }(p<0.05) \text {. }\end{array}$} \\
\hline
\end{tabular}

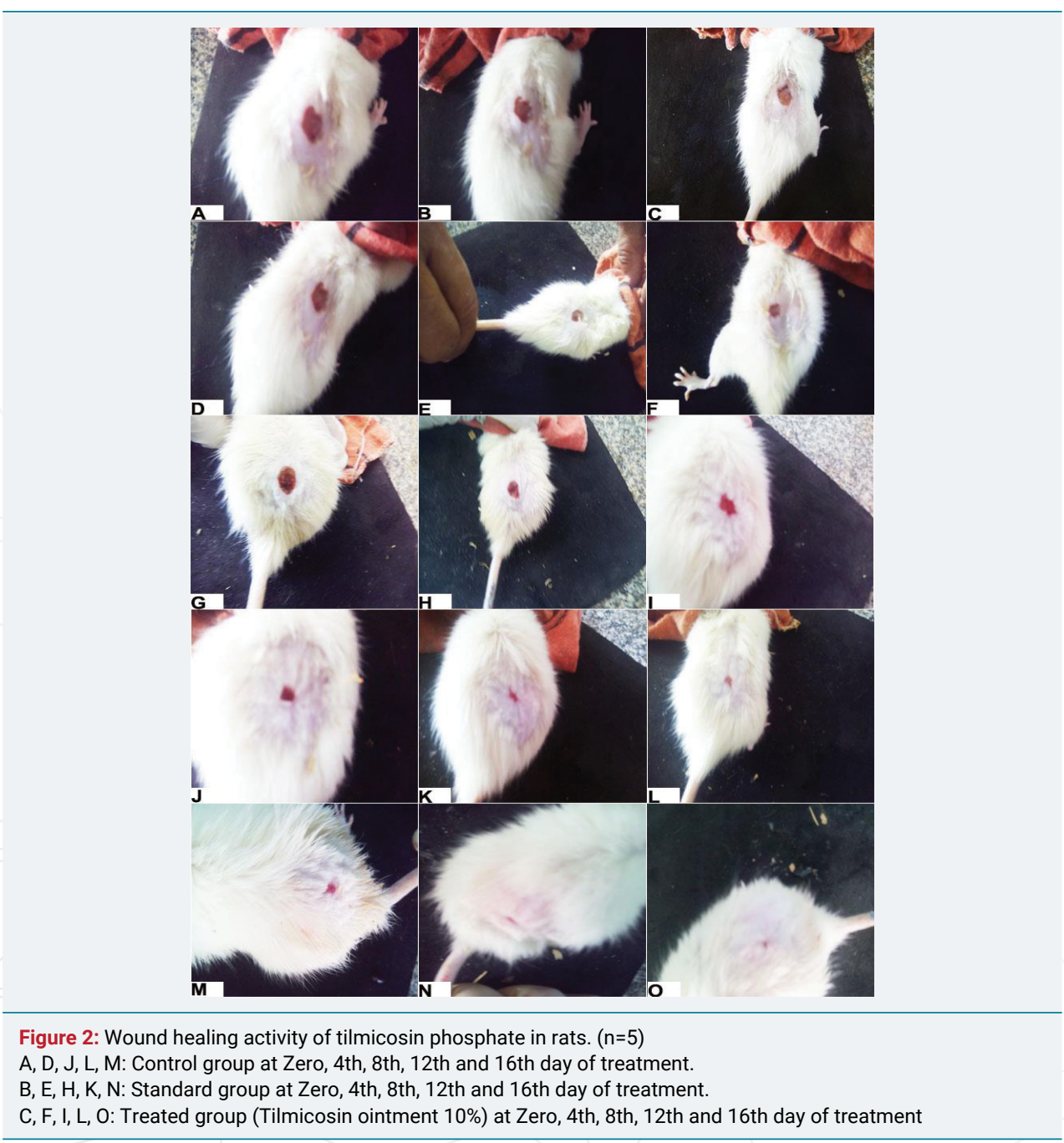


the control group, whereas the wound closure took about 22 days for complete healing in the control non treated group. Complete wound healing was observed in the group treated with the Tilmicosin phosphate ointment and standard group were seen in shorter period (18 days (in comparison to wound of the control group, (22 days).

\section{Effect of tilmicosin phosphate on Liver function}

Oral administration of tilmicosin phosphate markedly elevated the liver enzymes (ALT, AST and Alkaline phosphatase), GGT, (Total proteins and cholesterol specially at $40 \mathrm{mg} / \mathrm{kg} \mathrm{b.wt).} \mathrm{Both} \mathrm{the} \mathrm{control} \mathrm{negative} \mathrm{group} \mathrm{and} \mathrm{Silymarin} \mathrm{(hepatoprotective}$ group) were significantly reduced the liver enzymes compared to control positive group (Paracetamol administered group). Oral administration of tilmicosin (20 and $40 \mathrm{mg} / \mathrm{kg} \mathrm{b.wt)} \mathrm{had} \mathrm{a} \mathrm{significant} \mathrm{hepatotoxic} \mathrm{effect} \mathrm{on} \mathrm{liver} \mathrm{enzymes} \mathrm{and} \mathrm{on} \mathrm{cells}$ as demonstrated by the histopathological findings of the liver as severe hepatic cell necrosis and degenerative changes with proliferation of the Van Kupffer cells had been demonstrated Table 4 and Figure 3.

\begin{tabular}{|c|c|c|c|c|c|c|c|c|c|c|}
\hline Group & $\begin{array}{c}\text { Dose } \\
\text { (mg/kg) } \\
\text { b.wt. }\end{array}$ & $\begin{array}{c}\text { GPT } \\
\text { (ALT) } \\
\text { IU/L }\end{array}$ & $\begin{array}{l}\text { GOT } \\
\text { (AST) } \\
\text { IU/L }\end{array}$ & $\begin{array}{l}\text { SALP } \\
\text { (IU/L) }\end{array}$ & $\begin{array}{c}\mathrm{TP} \\
(\mathrm{mg} / \mathrm{dl})\end{array}$ & $\begin{array}{c}\text { GGT } \\
(\text { IU/L) }\end{array}$ & $\begin{array}{c}\text { Albumin } \\
\text { (IU/L) }\end{array}$ & $\begin{array}{l}\text { Globulin } \\
\text { (IU/L) }\end{array}$ & A/G ratio & $\begin{array}{l}\text { Cholesterol } \\
(\mathrm{mg} / \mathrm{dL})\end{array}$ \\
\hline $\begin{array}{c}\text { Normal Saline (Nacl } \\
0.9 \% \text { W/V) Control } \\
\text { Negative }\end{array}$ & $5 \mathrm{ml} / \mathrm{kg}$ & $40.00 \pm 2.00^{c}$ & $153.40 \pm 3.9^{d}$ & $561.6 \pm 2.4^{c}$ & $6.3 \pm 0.1^{c}$ & $9.00 \pm 0.7^{c}$ & $2.8 \pm 0.1^{c}$ & $3.4 \pm 0.05^{c}$ & $0.84 \pm 0.04^{c}$ & $86.2 \pm 1.5^{c}$ \\
\hline $\begin{array}{l}\text { Control Positive } \\
\text { (Paracetamol) }\end{array}$ & $\begin{array}{c}400 \mathrm{mg} / \\
\mathrm{kg}\end{array}$ & $88 \pm 0.7^{b}$ & $183.4 \pm 2.8^{c}$ & $613 \pm 2.6^{c}$ & $6.7 \pm 0.08^{b}$ & $9.6 \pm 0.8^{c}$ & $3.02 \pm 0.05^{c}$ & $3.7 \pm 0.04^{\mathrm{a}}$ & $0.81 \pm 0.01^{c}$ & $83.8 \pm 1.7^{c}$ \\
\hline $\begin{array}{l}\text { - Tilmicosin } \\
\text { Phosphate } \\
\text { - Paracetamol }\end{array}$ & $\begin{array}{c}20 \mathrm{mg} / \mathrm{kg} \\
400 \mathrm{mg} / \\
\mathrm{kg}\end{array}$ & $87 \pm 1.4^{b}$ & $200 \pm 1.8^{b}$ & $630.8 \pm 2.3^{b}$ & $6.3 \pm 0.08^{c}$ & $12.2 \pm 0.3^{b}$ & $2.7 \pm 0.04^{c}$ & $3.6 \pm 0.07^{b}$ & $0.76 \pm 0.01^{c}$ & $74.8 \pm 0.8^{c}$ \\
\hline $\begin{array}{l}\text { - Tilmicosin } \\
\text { Phosphate } \\
\text { - Paracetamol }\end{array}$ & $\begin{array}{c}40 \mathrm{mg} / \mathrm{kg} \\
400 \mathrm{mg} / \\
\mathrm{kg}\end{array}$ & $177.2 \pm 2.5^{\mathrm{a}}$ & $243.2 \pm 2.6^{a}$ & $717.8 \pm 2.3^{a}$ & $6.9 \pm 0.07^{a}$ & $16.6 \pm 0.05^{a}$ & $3.4 \pm 0.04^{\mathrm{a}}$ & $3.5 \pm 0.03^{c}$ & $0.96 \pm 0.01^{c}$ & $105 \pm 0.9^{a}$ \\
\hline $\begin{array}{l}\text { - Silymarin } \\
\text { - Paracetamol }\end{array}$ & $\begin{array}{c}200 \mathrm{mg} / \\
\mathrm{kg} \\
400 \mathrm{mg} / \\
\mathrm{kg}\end{array}$ & $34.2 \pm 2.1^{c}$ & $105.6 \pm 3.2^{\mathrm{e}}$ & $600 \pm 1.6^{c}$ & $6.5 \pm 0.08^{c}$ & $11.8 \pm 0.8^{d}$ & $3.2 \pm 0.08^{b}$ & $3.2 \pm 0.06^{d}$ & $0.97 \pm 0.01^{c}$ & $81.6 \pm 2.1^{c}$ \\
\hline
\end{tabular}

Means within the same column having the same or no superscripts denote non-significant variations ( $p>0.05)$; $\mathbf{a}$ : represent the significant level at $(p<0.001)$; $\mathbf{b}$ : Represent the significant level at $(p<0.01)$; $c$ and $d$ : represent the significant level at $(p<0.05)$.

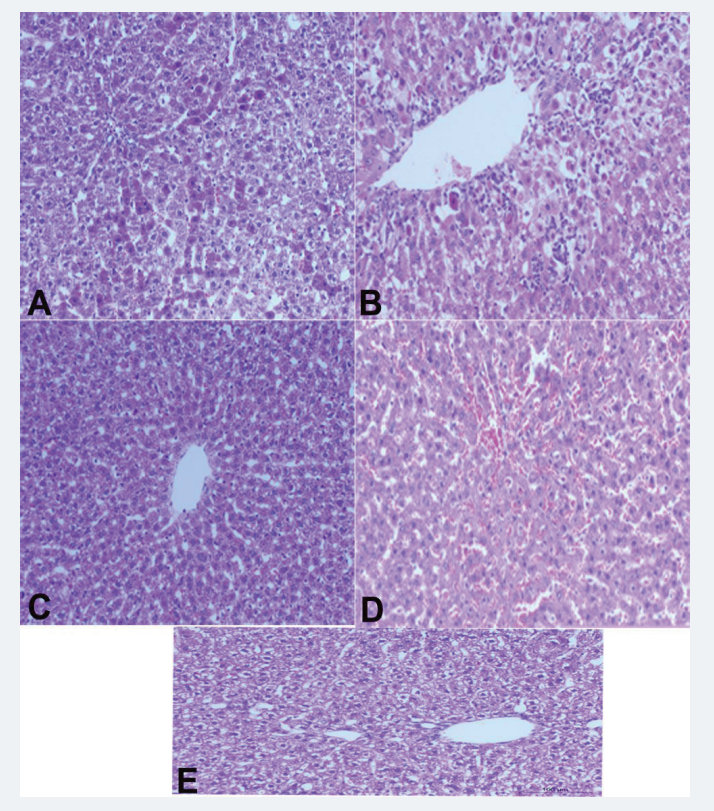

Figure 3: Hepatotoxic effects of tilmicosin $20 \mathrm{mg}, 40 \mathrm{mg}$ and Paracetamol on liver cells (severe degenerative changes and inflammation with proliferation of the Vankupffer cells, central vein dilatation and necrosis in (tilmicosin 40mg/kg b.wt). A:paracetamo,. B:T2, c: control negative saline, D: T1, E: salymarin. 


\section{Investigation the Analgesic effect of tilmicosin phosphate}

Hot plate test: Oral administration of tilmicosin phosphate at different dose levels of $(20$ and $40 \mathrm{mg} / \mathrm{kg}$ b.wt.) resulted in significant prolongation of the reaction time $(P<0.05)$. Higher dose of the tilmicosin phosphate $(40 \mathrm{mg} / \mathrm{kg})$ induced its analgesic effect at 1, 2, 3 and 5 hours. Maximum latency time of 20 and $40 \mathrm{mg} / \mathrm{kg}$ of tilmicosin phosphate was observed at 3 hours. In addition, Paracetamol ${ }^{\circledR}$ treated group produces significantly increase in the latency time with maximum occurred at 2 hours after administration of the drug and completed till 5 hours. The lower dose $(20 \mathrm{mg} / \mathrm{kg})$ showed significant increase in latency time at 4 and 5 hours in comparison with control group (Figure 4A).

Tail immersing Method: Also pre-treatment with tilmicosin phosphate at dose levels of (20 and $40 \mathrm{mg} / \mathrm{kg}$ b.wt.) induced analgesic activity in a dose dependent manner. Higher dose of the tilmicosin phosphate $(40 \mathrm{mg} / \mathrm{kg})$ induced its analgesic effect at 1, 2, 3 and 5 hours. Maximum latency time of $40 \mathrm{mg} / \mathrm{kg}$ of tilmicosin phosphate was observed at 5 hours. The lower dose $(20 \mathrm{mg} / \mathrm{kg})$ showed significant increase in latency time at 3 hours in comparison with control group (Figure 4B).

Writhing test: The higher dose of the tilmicosin phosphate ( $40 \mathrm{mg} / \mathrm{kg}$ b.wt.) has reduced number of writhes with maximum levels at 3 hours and continued till 5 hours with percentage of inhibition (100\%) in comparison with control non treated group, whereas the lower dose of the tilmicosin phosphate $(20 \mathrm{mg} / \mathrm{kg} \mathrm{b.wt}$.) and standard groups $\left(\right.$ Paracetamol $^{\circledR}$ ) showed percentage of inhibition $(60 \%, 80 \%$ and $100 \%$ ) respectively. Tilmicosin phosphate was evaluated for its peripheral analgesic effect using acetic acid induced writhing test (Figure 4C).

\section{Evaluation the Anti-pyretic effect of tilmicosin phosphate}

Paracetamol and tilmicosin phosphate showed significantly decrease in the yeastelevated rectal temperature compared to control group. The antipyretic effect started at $1 \mathrm{hr}$ in comparison with control group and the antipyretic effect is maintained for 4 hrs post oral administration of the drugs (Table 5).

\section{Valuation the Anti-inflammatory effect of tilmicosin phosphate}

Tilmicosin phosphate $(20$ and $40 \mathrm{mg} / \mathrm{kg}$ ) exhibited anti-inflammatory activity against formalin induced paw edema as that induced by standard diclofenac sodium (30 mg/kg) for 4 hours post administration (Figure 4D).

\section{Measurement the effect of tilmicosin phosphate on sleeping time (Hypnotic)}

Pre-treatment with tilmicosin phosphate orally at dose levels of 20 and $40 \mathrm{mg} /$ kg body weight, orally, before induction of sleeping by thiopental sodium induced significant $(P<0.05)$ increase in sleeping time respectively in comparison with the control group (Figure 4E).

\section{Effect of tilmicosin phosphate on the intestinal motility of rabbits}

Tilmicosin phosphate revealed inhibitory effect on the intestinal motility, concentrations lower than $0.3 \mathrm{gm} / \mathrm{ml}$ bath produced no effect on the force or frequency of intestinal contractions while concentration of $0.5 \mathrm{gm} / \mathrm{ml}$ bath induced slight inhibition in the force of contractions and marked inhibition was obtained at $1 \mathrm{gm} /$ $\mathrm{ml}$ bath. Complete relaxation was obtained at $7.5 \mathrm{gm} / \mathrm{ml}$ bath. Trials had been made to determine the site of action of the tilmicosin phosphate on the rabbitss intestine; the probability of an atropine -like activity was tested by adding acetylcholine in the presence of effective dose of the extract. Moreover the possibility of nicotine like effect was studied by adding a small dose of nicotine in the presence of effective dose of the extract in addition. The results indicated that tilmicosin phosphate didn't have 
atropine like action, since the addition of acetylcholine $(0.25 \mathrm{ml}$ of $1.1 \mathrm{X} 10-7 \mathrm{mmol} / \mathrm{L})$ modify the inhibitory effect of tilmicosin phosphate $(2.5 \mathrm{gm} / \mathrm{ml}$ bath $)$ as cause marked stimulation after tilmicosin adding. Furthermore addition of small dose of nicotine sulphate $(0.125 \mathrm{ml}$ of $10 \mu \mathrm{g} / \mathrm{ml})$ induced stimulatory effect in the presence of the inhibitory dose of tilmicosin phosphate $(2.5 \mathrm{gm} / \mathrm{ml}$ bath) (Figure $4 \mathrm{~F}$ and 5$)$.

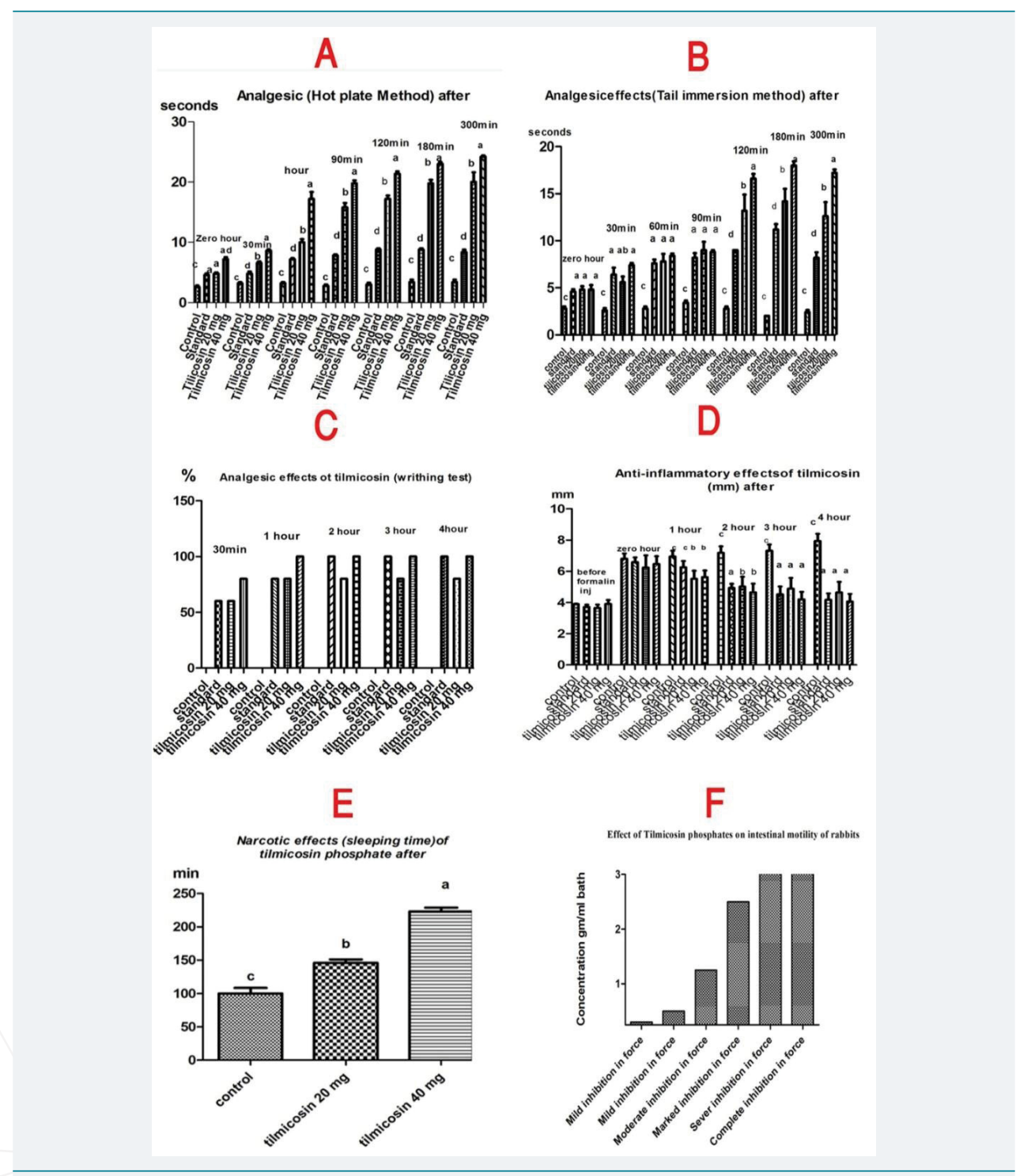

Figure 4: Effect of tilmicosin phosphate on A: Analgesic (hot plate), B: (Tail immersion), C: (writhing test), D (Antiinflammatory), E: (Hypnotic) and F: (relaxant).

Table 5: Anti-pyretic effect of tilmicosin phosphate in hyperthermic rats $(n=5)$.

\begin{tabular}{|c|c|c|c|c|c|c|c|c|c|c|c|}
\hline \multirow{3}{*}{ Group } & \multirow{3}{*}{$\begin{array}{c}\text { Dose } \\
\mathrm{mg} / \mathrm{kg} . \\
\text { body weight }\end{array}$} & \multicolumn{10}{|c|}{ Body temperature $\left({ }^{\circ} \mathrm{C}\right)$} \\
\hline & & \multirow[t]{2}{*}{$\begin{array}{c}\text { Basal } \\
\text { rectal } \\
\text { temperature }\end{array}$} & \multirow[t]{2}{*}{$\begin{array}{c}18 \mathrm{hrs} \\
\text { from } \\
\text { yeast injection }\end{array}$} & $\begin{array}{c}30 \\
\mathrm{~min}\end{array}$ & $\begin{array}{c}60 \\
\min \end{array}$ & $\begin{array}{c}90 \\
\mathrm{~min}\end{array}$ & $\begin{array}{l}120 \\
\mathrm{~min}\end{array}$ & $\begin{array}{l}150 \\
\min \end{array}$ & $\begin{array}{l}180 \\
\mathrm{~min}\end{array}$ & $\begin{array}{l}210 \\
\min \end{array}$ & $\begin{array}{l}240 \\
\mathrm{~min}\end{array}$ \\
\hline & & & & \multicolumn{8}{|c|}{ after drug administration } \\
\hline Control & - & $36.5 \pm 0.14$ & $37.40 \pm 0.18^{\mathrm{a}}$ & $37.7 \pm 0.1^{c}$ & $37.6 \pm 0.21^{\mathrm{a}}$ & $37.8 \pm 0.2^{\mathrm{a}}$ & $36.9 \pm 0.22^{\mathrm{a}}$ & $36.8 \pm 0.2^{c}$ & $36.8 \pm 0.11^{\mathrm{b}}$ & $36.8 \pm 0.10^{\mathrm{a}}$ & $36.9 \pm 0.09^{\mathrm{a}}$ \\
\hline $\begin{array}{c}\text { Standard } \\
\left(\text { Paracetamol }{ }^{\circledast}\right)\end{array}$ & 150 & $36.00 \pm 0.20$ & $36.8 \pm 0.09^{a}$ & $36.06 \pm 0.3^{a}$ & $35.6 \pm 0.09^{b}$ & $35.4 \pm 0.1^{c}$ & $35.2 \pm 0.14^{b}$ & $35.2 \pm 0.1^{\mathrm{a}}$ & $35.2 \pm 0.19^{c}$ & $35.4 \pm 0.14^{b}$ & $35.1 \pm 0.04^{\circ}$ \\
\hline \multirow{2}{*}{$\begin{array}{l}\text { Tilmicosin } \\
\text { phosphate }\end{array}$} & 20 & $36.1 \pm 0.25$ & $37.5 \pm 0.26^{\mathrm{a}}$ & $37.1 \pm 0.2^{b}$ & $36.8 \pm 0.36^{b}$ & $36.5 \pm 0.1^{b}$ & $36.5 \pm 0.32^{b}$ & $36.4 \pm 0.1^{\mathrm{cb}}$ & $36.4 \pm 0.27^{b}$ & $36.5 \pm 0.19^{c}$ & $36.2 \pm 0.2^{b}$ \\
\hline & 40 & $36.1 \pm 0.09$ & $36.8 \pm 0.26^{\mathrm{a}}$ & $36.2 \pm 0.07^{a}$ & $36.1 \pm 0.29^{b}$ & $36.06 \pm 0.1^{b}$ & $36.00 \pm 0.09^{b}$ & $36.02 \pm 0.1^{b}$ & $36.1 \pm 0.10^{b}$ & $36.4 \pm 0.05^{d c}$ & $36.4 \pm 0.2^{b}$ \\
\hline
\end{tabular}

Means within the same column having the same or no superscripts denote non-significant variations $(p>0.05)$, a: represent the significant level at ( $<<0.001) b$ :Represent the significant level at $(p<0.01)$., $c$ and d: represent the significant level at $(p<0.05)$. 


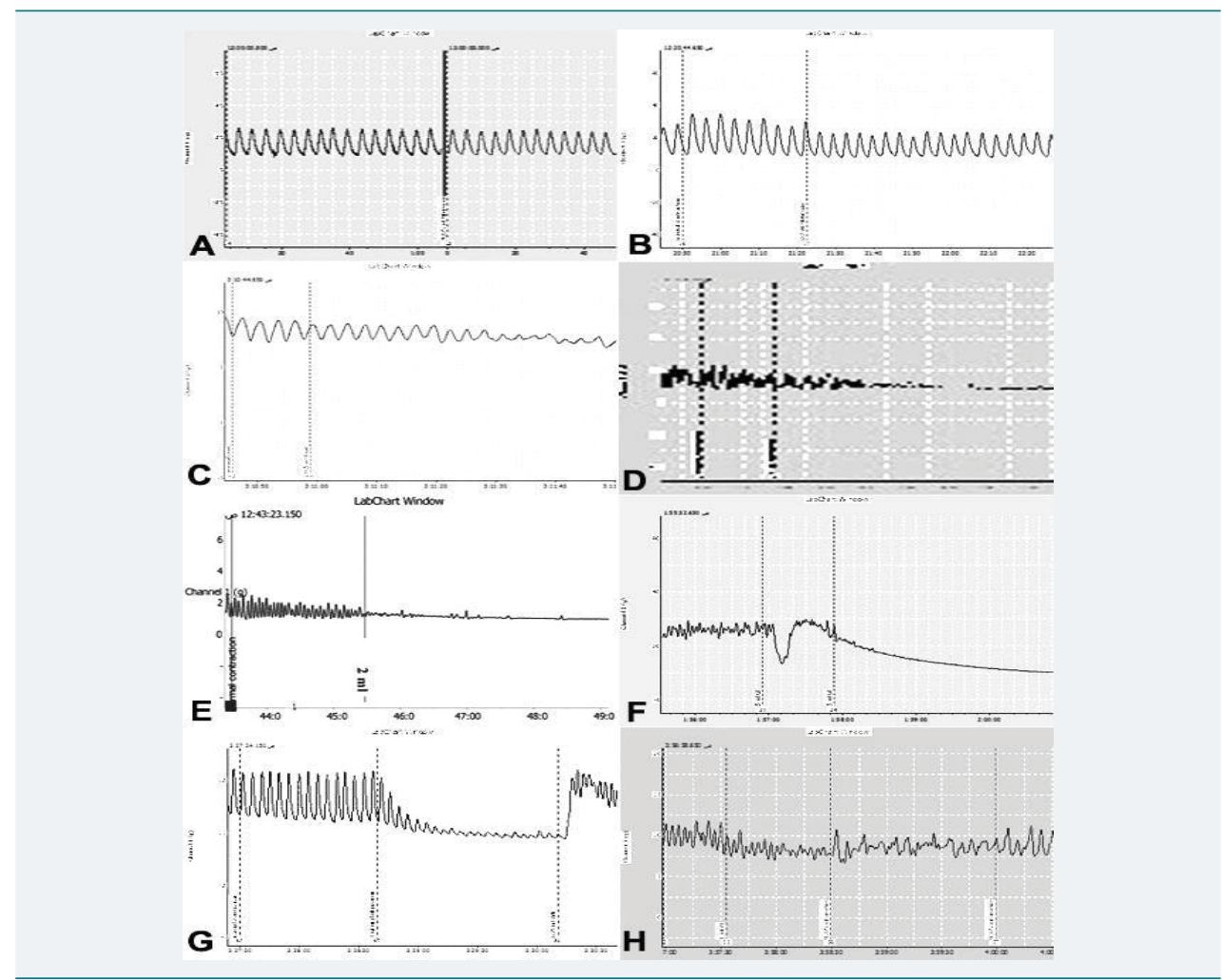

Figure 5: Effect of Tilmicosin phosphate on the intestinal motility of rabbits.

A: $0.3 \mathrm{gm} / \mathrm{ml}$ bath has no effect on intestinal muscles. B: $0.5 \mathrm{gm} / \mathrm{ml}$ bath induced mild inhibition in force.

C: $1.25 \mathrm{gm} / \mathrm{ml}$ bath induced moderate inhibition in force. D: $2.5 \mathrm{gm} / \mathrm{ml}$ bath induced severe inhibition in force.

$\mathrm{E}: 5 \mathrm{gm} / \mathrm{ml}$ bath induced marked relaxation. $\mathrm{F}: 7.5 \mathrm{gm} / \mathrm{ml}$ bath induced complete relaxation.

G: Tilmicosin phosphate $(2.5 \mathrm{gm} / \mathrm{ml}$ bath) induced marked inhibition followed by $0.25 \mathrm{ml}$ acetylcholine chloride modify the inhibitory effect of the drug through inducing marked stimulation.

$\mathrm{H}$ : Tilmicosin phosphate $(2.5 \mathrm{gm} / \mathrm{ml}$ bath) induced marked inhibition followed by $0.125 \mathrm{ml}$ nicotine sulphate induced marked stimulation.

\section{Effect on uterine motility of female rats at different stages of sex cycle}

No significant effect observed for tilmicosin phosphate on the uterine contractility of female rats at different stages of sex cycle. Tilmicosin phosphate induced no effect on the uterine contractility from concentrations of $0.5 \mathrm{gm} / \mathrm{ml}$ bath at any stage of sex cycle till $12.5 \mathrm{gm} / \mathrm{ml}$ bath (Figure 6).

\section{Discussion}

Adverse or beneficial events associated with drug uses have an important impact especially in commonly used drugs for well use of drugs in multiple forms, dispensing or administrations [28]. Tilmicosin commonly used idrug in veterinary medicine and at high dose has some adverse effects such as anaphylaxis, cardiotoxic, collapse and transient swelling at the site of injection [5] but also has beneficial activities must be explored. To the best of our knowledge no previous studies reported about effects of tilmicosin on wound healing, ulcer treatment, hypnotic and relaxant effects on intestine or on utras. The current studies aimed for revealing multiple beneficial activity for commonly used drug (tilmicosin).

Tilmicosin phosphate possessed anti-ulcerogenic effect at dose levels of 20 and $40 \mathrm{mg} / \mathrm{kg}$ body weight, and the higher dose is more potent. Tilmicosin phosphate and Ranitidine ${ }^{\circledR}$ treated groups showed a significant decrease in the ulcer index in comparison to the control group. Stomachs of rats treated with higher dose of the drug ( $40 \mathrm{mg} / \mathrm{kg}$ body weight), showed no congestion and the stomach appearance was normal. The decrease in the gastric congestion might be attributed to the antimicrobial activity of tilmicosin against Helicobacter bacteria which is the most common reason for gastric ulcer. Our results were agreed with [29] they reported about the gastro- 


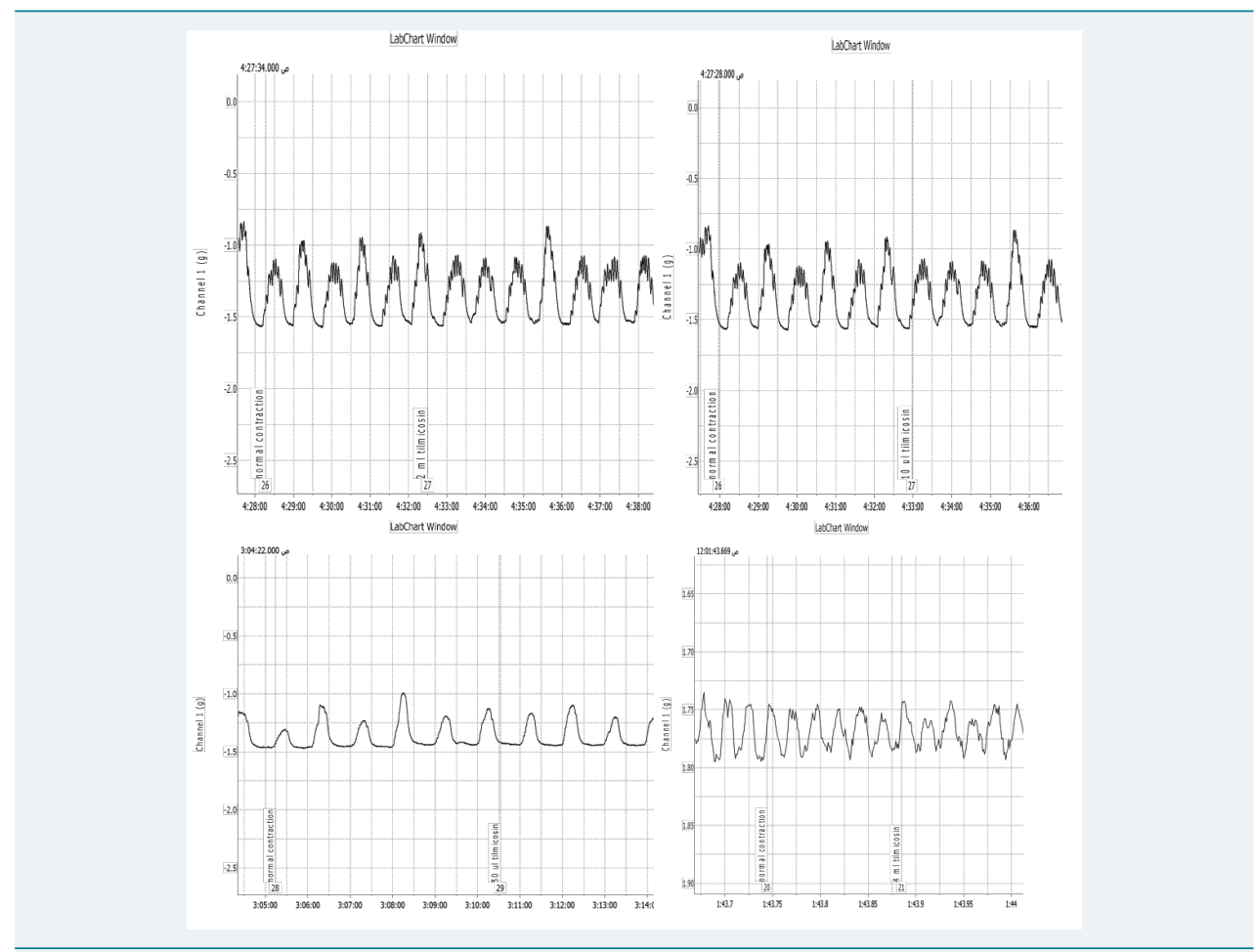

Figure 6: Effect of Tilmicosin phosphate on isolated uterus of female rats in different stages of sex cycle (No change had been determined after tilmicosin adding on the uterine muscles from $0.5 \mathrm{gm} / \mathrm{ml}$ of the drug till 12.5 $\mathrm{gm} / \mathrm{ml}$ bath.

protective effect of azithromycin caused by $H$ ducreyi [30]. From the obtained results we suggest that the tilmicosin phosphate may be beneficial in the prevention and/or treatment of gastric lesions.

Wound healing is a complicated process involving four main processes, namely, hemostasis, inflammation, proliferation and remodeling [9]. This study showed that, the topical application of tilmicosin phosphate ointment when used at concentrations of $(10 \%)$ enhanced wound healing process in rats. The significant wound healing activity revealed due to their ability for decreasing the response of inflammation at the wound area. The result was come in accordance with [31] they found that local application of antibiotics could reduce the inflammatory response in wound healing. Also this result come in accordance with [32] about the role of Rapamycin on Wound Healing in wound healing as affected all steps of the wound healing process by decreasing the inflammatory cell number, angiogenesis, and myofibroblast proliferation.

Hepatoprotective effects of tilmicosin had been investigated at both 20 and $40 \mathrm{mg} /$ $\mathrm{kg}$ b.wt. Orally for 7 days with using silymarin drug as a standard hepatoprotective drug. From the obtained data liver enzymes elevated severely especially at dose of $40 \mathrm{mg}$ ALT and AST are important serum enzymes in the liver and monitoring their concentrations usually help to liver diseases [33]. Administration of the tilmicosin phosphate severely affected most of the liver function parameters. The serum concentration of ALT and AST which are markers of hepatocellular damage and myocardial infarction [34] were significantly affected by the drug. This indicated by histopathological examination of the liver of the experimented animals as presence of hepatocellular vacuolar degeneration. These lesions may have occurred as a result of metabolism of the drug by the liver which serves as the primary organ of biotransformation [35] Also this attributed to the hepatic necrosis, dilatation in the central vein and severe vascular inflammation caused by macrolides antibiotic groups, this come in accordance with [36] as reported that macrolides inhibit the P-glycoprotein transport of the liver which responsible for ATP transfer. 
Hot-plate, tail immersion and acetic acid-induced writhing methods are useful techniques for the evaluation of centrally- and peripherally- acting analgesic drugs, respectively [37]. Tilmicosin phosphate possessed central and peripheral analgesic activities at both doses $(20-40 \mathrm{mg} / \mathrm{kg}$, orally). These results were come in agreement with [38] they found that both roxithromycin and erythromycin had ant nociceptive effect.

The peripheral analgesic activity was determined by acetic acid induced writhing test. The pain is induced due to liberation of endogenous substances as well as other pain mediators such as arachodonic acid via cyclooxygenase and prostaglandin biosynthesis especially PGE2 and PGF $2 \alpha$, which then stimulate the pain nerve endings $[39,40]$ Tilmicosin phosphate significantly $(\mathrm{p}<0.05)$ inhibited acetic acid-induced writhes in mice. The inhibition in the pain might attributed to inhibition of pain mediators PGE2 which achieved by all macrolides [41] all macrolides via inhibition of hyperalgesic mediators such as PGE2, which are predominantly involved in peripheral pain [38].

Tilmicosin phosphate showed significant anti-pyretic effect in feverish rats in both doses $(20,40 \mathrm{mg} / \mathrm{kg}$, orally). Elevations in body temperature occur when concentrations of prostaglandin E2 (PGE2) increase within certain areas of the brain. The antipyretic effect may be due to inhibition of prostaglandin synthesis within the hypothalamus by blocking the cyclo-oxygenase enzyme activity [42]. This come in accordance with [43] about the effects of tilmicosin on body temperature and also azithromycin has been reported to possess antipyretic activities and was reported to inhibit centrally the synthesis of prostaglandin in the brain [44] and also as that's reported about azithromycin and clazithromycin hypothermic effects [45].

Induction of paw edema in rat by different agents such as formalin or carrageenan is believed to be biphasic; in the first phase (1hour) serotonin and histamine are released while in the second phase (over 1hour) prostaglandins, cyclooxygenase products are mediated and kinins provide the continuity between the two phases [46]. The result of this study revealed that tilmicosin phosphate significantly reduced paw edema in rats in a dose dependent manner at 2 and $3 \mathrm{hrs}$. The anti-inflammatory and antipyretic activities of tilmicosin phosphate may be due its effects on induced macrophage apoptosis on the synthesis of pro inflammatory CXCL-8 as reported for tulathromycin in cattle [47].

The most important step in evaluating drug action on the central nervous system (CNS) is to observe the behavior of the tested animals. Substances that have CNS depressant activity either decrease the time for onset of sleep or prolong the duration of sleep or both. The result of this study showed that both doses $(20,40 \mathrm{mg} / \mathrm{kg}$, orally) of tilmicosin phosphate produced a significant increase in the sleeping time induced by the thiopental sodium (Anapental@), in a dose-dependent manner; thus suggesting a profound sedative activity. Like many other centrally acting drugs, barbiturates acts on the cerebral cortex to produce their actions [48]. Thiopental sodium, a barbiturates class hypnotic drug by enhancing the activity of gamma-amino-butyric acid type A (GABAA) receptor increases the chloride conductance and potentiates GABAA mediated postsynaptic inhibitors [49]. The prolongation of thiopental sodium-induced sleeping time may be attributed to an inhibition of pentobarbital metabolism [50]. The prolongation of thiopental sodium sleeping time by the drug suggests that thiopental sodium- induced hypnosis is a good index of CNS depressant activity as reported by [51].

The effect of tilmicosin phosphate on the intestinal motility of isolated rabbit duodenum revealed that tilmicosin phosphate inhibited the intestinal contractility in a dose dependent manner. These results were came in accordance with [52,53] 
who found to erythromycin macrolide antibiotic possess a concentration-dependent relaxant effects on the above intestinal parts but in different degree of intensity besides, erythromycin inhibits rat muscles contraction through the inhibition of calcium in flux and the modulation of intracellular calcium movement so depending on these data this might be also the same cause of the inhibitory effects of tilmicosin as reported by [54]. In the same way, [55] stated that azithromycin has a concentration-dependent, epithelium-independent, direct relaxant effect on muscles. Tilmicosin phosphate has no effects the uterine motility during non- pregnant (estrus and non-estrus) and pregnancy stages. These obtained results came in agreement with those obtained by [56] who stated that in vitro smooth muscle tissue studies, found that tilmicosin did not elicit contractile activity in rat uterus, or rat vas deferens.

We concluded that administration of tilmicosin phosphate orally has an important gastric cytoprotective against ulcer induction, wound healing activity, hypnotic, antiinflammatory, Antipyretic, Analgesic; besides anti-spasmodic action but at higher doses showed hepatotoxicity.

\section{References}

1. Etminan M, Samii A. Pharmacoepidemiology I: A Review of Pharmacoepidemiologic Study Designs. Pharmacother 2004; 24: 964-969. Ref.: https://goo.gl/rydTzd

2. WHO. Programme for International Drug Monitoring. http://www.who.int/medicines/areas/quality safety/safety_efficacy/National_PV_Centres_Map/en/. 2014.[Acessed in March 2015].

3. Papich MG, Riviere JE, Ames A. Chloramphenicol andderiva-tives, macrolides, lincosamides, and miscellaneous antimicro-bials," In in Veterinary Pharmacology and Therapeutics, Adams, H.R.E., " ed. (lowa, USA, lowa State University Press,), 2001. 868-897.

4. Susan LHG, Tucker DT, Robin SR. A study of tilmicosin residues in milk following subcutaneous administration to lactating dairy cows. Can Vet J. 1993; 34: 619-621. Ref.: https://goo.gl/9iiMe6

5. Gheith I, El-Mahmoudy A, Elmajdoub A, Awidat A. Pharmacovigilance of Tilmicosin in Mice. Act Scient Vet. 2015; 43: 1318. Ref.: https://goo.gl/eNSjT2

6. McGuigan MA. Human exposures to tilmicosin (MICOTIL).Vet Hum Toxicol. 1994; 36: 306-308. Ref.: https://goo.gl/jNykHV

7. Hardy D J, Hanson CW, Hensey DM, Beyer JM, Fernandes PB. Susceptibility of Campylobacter pylori to macrolides and fluoroquinolones. J Antimicrob Chemother. 1998; 22: 631-636. Ref.: https://goo.gl/qZrNaU

8. Nakagawa Y, Itai S, Yoshida T, Nagai T. Physicochemical properties and stability in the acid solution of a new macrolide antibiotic, clarithromycin, in comparison with erythromycin. Chem Pharm Bull. 1992; 40: 725-728. Ref.: https://goo.gl/iN6ypq

9. Enoch S, Leaper DJ. Basic science of wound healing. Surg. 2005; 23: 37-42. Ref.: https://goo.gl/TLNNuS

10. Dash DK, Yeligar VC, Nayak SS, Ghosh T, Rajalingam, et al. Evaluation of hepatoprotective and antioxidant activity of Ichnocarpus frutescens (Linn.) R.Br. on paracetamol-induced hepatotoxicity in rats. Trop J Pharm Res. 2007; 6: 755-765. Ref.: https://goo.gl/PB2VDG

11. Carvalho CA, Fernandes $\mathrm{Km}$, Matta Slp, Silva MB, Oliveira LL, et al. Evaluation of antiulcerogenic activity of aqueous extract of Brassica oleracea var. capitata (cabbage) on wistar rat gastric ulceratio. Arq Gastroenterol. 2011; 48: 276-282. Ref.: https://goo.gl/wfbRVg

12. Shuai W, Yong-rui B, Yun-Peng D, Xian-Sheng M, Ting-Guo K. Evaluation of gastric ulcer model based on gray-scale image analysis. African J Microbiol Res. 2011; 5: 1285-1290. Ref.: https://goo.gl/mQYdrr

13. Khayyal MT, El-Ghazaly MA, Kenawy SA, Seif-El-Nasr M, Mahran LG, et al. Antiulcerogenic effect of some gastrointestinally acting plant extracts and their combination. Arzneimittelforschung. 2001 51: 545-553. Ref.: https://goo.gl/oRCUxd

14. Ezekwe $\mathrm{Cl}$. Determination of ulcer protecting effect of ethanol extract of Gongronema latifolium in rats. African J Biotechnol. 2013; 12: 5705-5708. Ref.: https://goo.gl/K83E2q

15. Farahpour MR, Habib M. Evaluation of the wound healing activity of an ethanolic extract of Ceylon cinnamon in mice. Veterinarni Medicina. 2012; 57: 53-57. Ref.: https://goo.gl/uuuNGN 
16. Cukjati D, Reberek S, Miklavi D. Estimation of the hepatoprotective method. Med Biol Eng Comput. 2001; 39: 263-271. Ref.: https://goo.gl/BKQFGT

17. Kanchana N, Sadiq AM. Hepatpoprotective effect of plumbago zeylanica on paracetamol induce liver toxcisty in rats. Int J Pharm Pharm Sci. 2011; 3: 151-154. Ref.: https://goo.gl/NLncN2Vella SJ,

18. Beattie P, Cademartiri R, Laromaine A, Martinez AW, et al. Measuring Markers of Liver Function Using a Micro-Patterned Paper Device Designed for Blood from a Fingerstick. Anal Chem. 2012; 84: 28832891. Ref.: https://goo.gl/weMS9J

19. Sithara AP, Ravi M, Mallya S, Sudhakara BS, Srikanth P. Experimental evaluation of analgesic and anti-inflammatory potential of leaves of Antidesma menasu on wistar albino rats. Int $\mathrm{J}$ Pharmacol and Clin Sci. 2013; 2: 105-112.

20. Mondal H, Saha S, Awang K, Hossain H, Ablat A, et al. Central-stimulating and analgesic activity of the ethanolic extract of Alternanthera sessilisin mice. BMC Complement Altern Med. 2014; 14: 398. Ref.: https://goo.gl/rBxKA7

21. Reddy SK, Kumar SA, Kumar VD, Ganapaty S. Anti-inflammatory and Analgesic Activities of Amorphophallus bulbifer (Roxb) KunthWhole Plant. Trop J Pharma Res. 2012; 11: 971-976. Ref.: https://goo.gl/5qUkry

22. Muhammad N, Saeed M, Kha H. Antipyretic, analgesic and anti-inflammatory activity of Viola betonici foliawhole plant. BMC Complement Altern Med. 2012; 12: 59. Ref.: https://goo.gl/xHzoZQ

23. De Faveri Favero F, Grando R, Nonato F, Sousa LMO, Queiroz NCA, et al. Artemisia annua L.: evidence of sesquiterpene lactones' fraction antinociceptive activity. BMC Compl Alter Med. 2014; 14: 266. Ref.: https://goo.gl/9fYDNY

24. Ramaker MJ. The Effect of a Neuroactive Steroid Analog and an Extrasynaptic GABA[subscript A] Receptor Agonist on Ethanol Consumption and Seeking in Mice". Scholar Arch. 2014; 35: 21. Ref.: https://goo.gl/CFwDZJ

25. Staff members of Department of Pharmacology, U.o.E. Pharmacological experiments on isolated preparations., Livingstone, E.a.S.L., ed. (Edinburgh, U.K), 1970; 60.

26. Marcondes FK, Bianchi FJ, Tanno AP. Determination of the estrous cycle phases of rats: some helpful considerations. Braz J Biol. 2002; 62: 609-614. Ref.: https://goo.gl/eswQuV

27. Snedecor GW, Cochran WG. Statistical Methods., lowa State University Press, ed. (Ames, USA.), $1982 ; 593$.

28. Gama H. Drug Utilization Studies. Arq Med. 2008; 22: 69-74. Ref.: https://goo.gl/4vN8D1

29. Jerry M, Zuckerman MD. Macrolides and ketolides: azithromycin,clarithromycin, telithromycin. Infect Dis Clin North Am. 2004; 18: 621-649. Ref.: https://goo.gl/snEqpT

30. Burette A, Glupczynski A. Helicobacter pylori: The Place of the New Macrolides in the Eradication of the Bacteria in Peptic Ulcer Disease. Infection. 1995; 23: 44-52. Ref.: https://goo.gl/dGaT1w

31. Xu L, Wang Y, Nguyen VT, Chen J. Effects of Topical Antibiotic Prophylaxis on Wound Healing Following Flapless Implant Surgery: A Pilot Study. J Periodontology. 2016; 3: 275-280. Ref.: https://goo.gl/WRQKn2

32. Ekici Y, Emiroglu E, Ozdemir H, Aldemir D, Karakayali $\mathrm{H}$, et al. Effect of Rapamycin on Wound Healing: An Experimental Study. Transplant Proc. 2007; 39: 1201-1203. Ref.: https://goo.gl/w2Fkz3

33. Wang TC, Su YP, Hsu TY, Yang CC, Lin CC. 28-day oral toxicity study of the aqueous extract from spider brake (Pteris multifida Poiret) in rats. Food Chem Toxicol. 2007; 45: 1757-1763. Ref.: https://goo.gl/Ao7X6n

34. Bergmeyer H U, Scheibe $P$, Wahlefeld AW. Optimization of methods for aspartate aminotransferase and alanine aminotransferase. Clin Chem. 1978. 24: 58-73. Ref.: https://goo.gl/n3qk5i

35. Baggot JD. Disposition and fate of drugs in the body. In John`s Veterinary Pharmacology and Therapeutics, Booth, W.H.a.L.E., ed. (Ludhiana, New Delhi,, Kalyani Publishers)1984; 36-70

36. King-Wing, Chow K, Choy AS, Kwan BC, Szeto C, et al. Clinical manifestation of macrolide antibiotic toxicity in CKD and dialysis patients. Clin Kidney J. 2014; 7: 507-512. Ref.: https://goo.gl/RkD8eh

37. Williamson EM, Okpako DT, Evans FJ. Pharmacological methods in phytotherapy research: In Selection, Preparation and Pharmacological Evaluation of Plant Materials. John Wiley C. 1996; 184186. 
38. Khobragade AA, Patel SB, Pophale RR, Vallish BN, Kosale SP. Analgesic and Anti-inflammatory Activity of Roxithromycin and Erythromycin, Alone and in Combination with Ibuprofen:An Animal Study. IOSR Journal of Pharmacy. 2012; 1: 15-21. Ref.: https://goo.gl/64cwfK

39. Khan H, Saeed M, Gilani A, Khan MA, Dar A, et al. The antinociceptive activity of Polygonatum verticillatum rhizomes in pain models. $J$ Ethnopharmacol. 2010; 127: 521-527. Ref.: https://goo.gl/ijXpYx

40. Taesotikul T, Panthong A, Kanjanapothi D, Verpoorte R, Scheffer JJC. Anti-inflammatory, antipyretic and antinociceptive activities of Tabernaemontana pandacaqui Poir. J Ethnopharmacol. 2003; 84: 31-35. Ref.: https://goo.gl/bbicTU

41. Vinadrell $\mathrm{P}$, Planas J, Torralba A. Inhibition of Erythromycin-lactobionate induced writhing by analgesic drugs. Farmaco Prat. 1980; 35: 133-140. Ref.: https://goo.gl/fcStwT

42. Math P, Mishra DK, Prajapati PK, Roshy J, Jha PK. Antipyretic activity of Madhukadi and Madhukadi Ghana-An Experimental study. Int J Pharma biol Arch. 2011; 2: 572-576.

43. Fajt VR. The effects of danofloxacin and tilmicosin on peripheral neutrophils in healthy cattle, on peripheral neutrophils in cattle with induced Pasteurella haemolytica pneumonia, and on body temperature measured via radiotelemetry in cattle with induced Pasteurella haemolytica pneumonia. lowa State. 2000. Ref.: https://goo.gl/vxcNQ7

44. Kavukçu S, Uĝuz A, Aydin A. Hypothermia from Azithromycin. J Toxicol Clin Toxicol. 1997; 35: 225226. Ref.: https://goo.gl/iBvD77

45. Cascio A, Colomba C, Antinori S, Paterson DL, Titone L. Clarithromycin Versus Azithromycin in the Treatment of Mediterranean Spotted Fever in Children: A Randomized Controlled Trial. Clin Infect Dis. 2002; 34: 154-158. Ref.: https://goo.gl/t12522

46. Cuman RKN, Bersani-Amado CA, Fortes ZB. Influence of type 2 diabetes on the inflammatory response in rats. Inflamm Res. 2001; 50: 460-465. Ref.: https://goo.gl/QZcajt

47. Fischer CD, Beatty JK, Duquette SC, Morck DW, Lucas MG, et al. Direct and Indirect Anti-Inflammatory Effects of Tulathromycin in Bovine Macrophages: Inhibition of CXCL-8 Secretion, Induction of Apoptosis, and Promotion of Efferocytosis. Antimicrob Agents Chemother. 2013; 57: 1385-1393. Ref.: https://goo.gl/VXGFvA

48. Bowman WC, Rand MJ. Text book of pharmacology. (New York, Blackwell Scientific publication), $1980 ; 267$.

49. Katzung BG. Basic and clinical pharmacology. In Lange Medical Books, Companies, M.H., ed. (New York:), 2001; 1064.

50. Kaul PN, Kulkarni SK. New drug metabolism inhibitor of marine origin. J Pharm Sci. 1978; 67: 12931296. Ref.: https://goo.gl/Txhrrm

51. Fujimori H, Cobb DP. Central nervous system depressant activity of MA 1337, 3-[3,4-m-chlorophenyl1-piperazyl propyl]- 2,4 (1H,3H) quinozolinedonehydrochloride. J Pharmacol Exp Ther. 1965; 148: 151-157. Ref.: https://goo.gl/GJHd4j

52. Koutsoviti-Papadopoulou M, Kounenis G, Elezoglou V. Effect of erythromycin on different parts of the rabbit intestine: comparison with motilin. Gen Pharmacol. 1994; 25: 93-96. Ref.: https://goo.gl/LTeqcz

53. Nissan A, Freund $H$, Hanani $M$. Direct inhibitory effect of erythromycin on human alimentary tract smooth muscle. Am J Surg. 2002; 183: 413-418. Ref.: https://goo.gl/5zDPah

54. England RCD, Norman RI, Elliott RA. Direct Inhibition of Rat Detrusor Muscle Contraction by Erythromycin. Neurourol Urodyn. 2004; 23: 273-279. Ref.: https://goo.gl/NAFVzT

55. Daenas C, Hatziefthimiou AA, Gourgoulianis KI, Molyvdas PA. Azithromycin has a direct relaxant effect on precontracted airway smooth muscle. Eur J Pharmacol. 2006; 28: 280-287. Ref.: https://goo.gl/JgzsdV

56. Modrit S. Pharmacokinetics and harmacodynamics properites of tilmicosin in sheep, cattle and rats. University of Florida.1997 